\title{
Parotid Adenoid Cystic Carcinoma Metastasizing to the Liver: A Case Report
}

\author{
Karaciğere Metastaz Yapan Parotis Adenoid Kistik Karsinomu: Bir Olgu Sunumu \\ iD Hatice Karaman, iD Arzu Erdem Tasdemir, iD Ipek Ozer, iD Merve Dogan
}

Kayseri City Hospital, Clinic of Pathology, Kayseri, Turkey

\begin{abstract}
Adenoid cystic carcinoma is a rare malignant neoplasm of the salivary gland. Salivary gland neoplasms constitute $3 \%$ of cancers of all sites, of which, 10-15\% are malignant. Though adenoid cystic carcinoma is the most common malignant tumor of the submandibular, sublingual and minor salivary glands, it accounts for only $15 \%$ of parotid cancers. They are generally slow-growing and spread relentlessly to adjacent structures. Hematogenous spread is more common than lymphatic spread, the common sites of metastasis being the lung, bone, liver, and brain. We present a case of multiple liver metastases occurring 3 years after surgery for adenoid cystic carcinoma of the parotid gland. The primary therapy, metastasis, and outcome of adenoid cystic carcinoma are discussed.

\section{$\ddot{O} Z E T$}

Adenoid kistik karsinom tükrük bezinin nadir görülen malign bir tümörüdür. Tükrük bezi neoplazileri tüm kanserlerin \%3'ünü oluşturur ve bunların \%10-15'i maligndir. Aynı zamanda adenoid kistik karsinom submandibuler, sublingual ve minör tükrük bezlerinin en sık malign tümörüdür. Parotis kanserlerinin sadece \%15'ini oluşturur. Bunlar genel olarak yavaş büyür ve çevre dokuya agresif yayılır. Hematojen yayılma, lenfatik yayılmadan daha yaygındır, yaygın metastaz bölgeleri akciğer, kemik, karaciğer ve beyindir. Parotis bezinde adenoid kistik karsinom olan ve ameliyattan 3 yll sonra multiple karaciğer metastazları görülen vakayı sunduk. Adenoid kistik karsinomun birincil tedavisi, metastazı ve sonucu tartışılmaktadır
\end{abstract}

\section{INTRODUCTION}

Adenoid cystic carcinoma (ACC) is a rare malignant neoplasm of the salivary gland. Salivary gland neoplasms constitute $3 \%$ of cancers of all sites, of which, $10-15 \%$ are malignant. Though ACC is the most common malignant tumor of the submandibular, sublingual and minor salivary glands, it accounts for only $15 \%$ of parotid cancers. They are generally slow-growing and spread relentlessly to adjacent structures. Hematogenous spread is more common than lymphatic spread, the common sites of metastasis being the lung, bone, liver, and brain (1-2). We present a case of multiple liver metastases occurring 3 years after surgery for ACC of the parotid gland.

\section{CASE}

A 60-year-old woman presented with a small swelling beneath the right ear lobe of 4 months duration. The swelling measured $2 \times 1 \mathrm{~cm}$ placed in the superficial part of the parotid and was not fixed. There was no facial nerve palsy or palpable cervical nodes. Fine-needle aspiration cytology (FNAC) was carried out which showed the lesion to be ACC. The clinical staging was T1, N0, M0. The patient underwent a total conservative parotidectomy after a metastatic workup. Histopathology revealed ACC with cribriform pattern and perineural invasion. 60 Gy adjuvant external beam radiotherapy was administered post-opera- tively to the parotid area and the neck. The patient was placed on regular follow-up. Three years after primary surgery, the patient presented with heaviness and pain in the right hypochondrium of 15 days duration. The patient was anicteric and abdominal examination revealed firm nodular and non-tender enlargement of the liver. There were no ascites. The surgical site and neck were clinically normal. The chest roentgenogram was normal. Ultrasonography (US) of the abdomen revealed multiple metastatic lesions scattered in both lobes. The core-needle biopsy was performed to distinguish primary and secondary from the lesion in the liver. Histopathological examination, the tumors consist of characterized by a nest of tumor cells interrupted by sharply punched-out spaces filled with a basophilic matrix that form infiltrative tubular and cribriform structure (Figure 1). The tumor cells show scant cytoplasm and typically have small angulated and hyperchromatic nuclei (Figure 2). Immunohistochemical examination revealed that tumor cells were positive stain for CD117 (Figure 3) typically restricted to inner epithelial cells and focal positive stain for S100 to peripheral myoepithelial cells but negative for CDX2, Heppar. This was in keeping with the diagnosis of ACC.

Liver function tests were normal and a US-guided FNAC revealed metastatic ACC. Since the lesions were multiple 
and scattered over both lobes of the liver, surgical option was not considered and the patient was offered palliative chemotherapy which she declined. She developed pedal edema and abdominal distention 20 months after detection of liver metastasis. On clinical examination, the patient

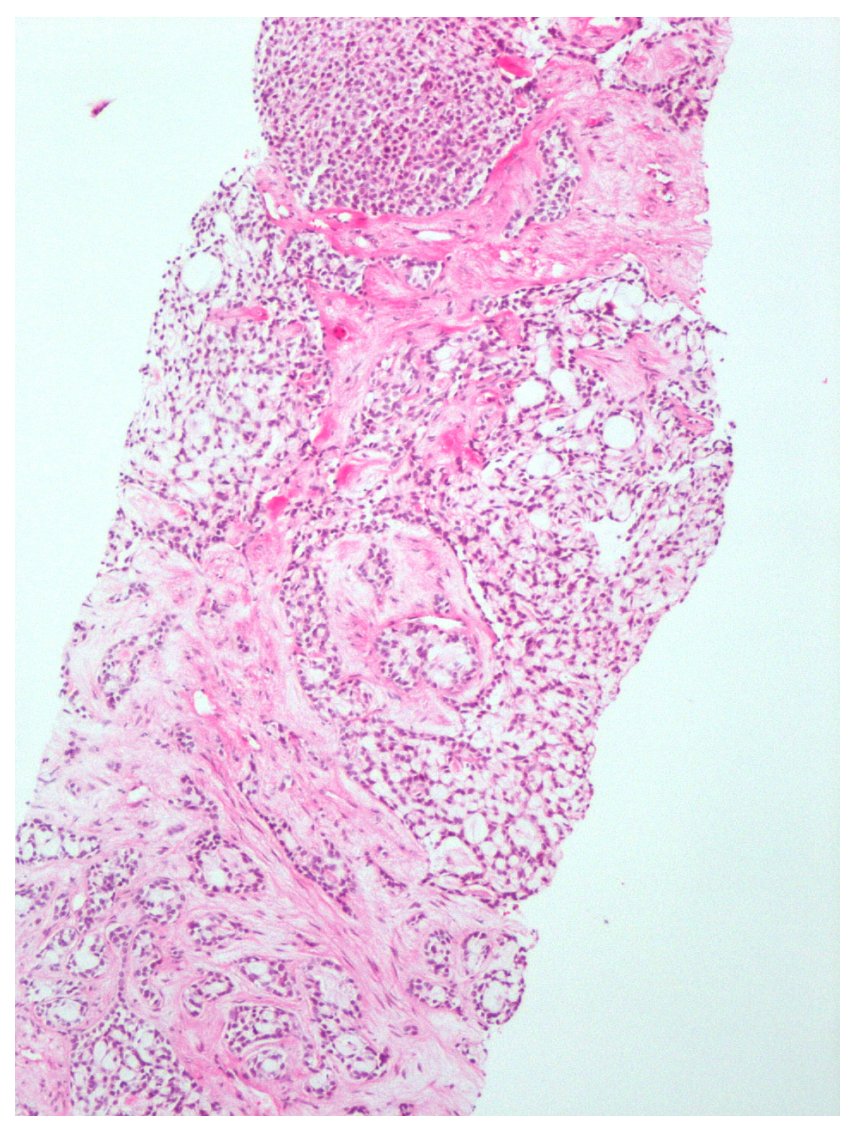

Figure 1: Hematoxylin/eosin staining of an adenoid cystic carcinoma (Magnification, $\times 100$ ).

\section{DISCUSSION}

Although ACC is the second most common malignant salivary gland neoplasm and constitutes approximately one-third of all salivary gland malignancies it constitutes only $15 \%$ of parotid neoplasms (1). As ACC is neurotropic, frozen section analysis of nerve margins is suggested especially when the nerve is grossly involved by the tumor. A total conservative or a radical parotidectomy is advocated for ACC though the main intent is to obtain a tumor-free area of at least $1 \mathrm{~cm}$. ACC, with its often unusually slow biologic growth, tends to have a protracted course and ultimately a poor outcome, with a 10-year survival reported to be less than $50 \%$ for all grades (2). These carcinomas typically show frequent recurrences and late distant metastases (3). In a retrospective review of 92 cases, tumor size greater than $4 \mathrm{~cm}$ was associated with an unfavorable clinical course (4). Cribriform and solid patterns seen histologically were thought to predict more biological aggressiveness while tubular patterns represented a more differentiated pattern of ACC. Over long periods of patient was anicteric but the liver had increased in size and the abdomen showed evidence of a little free fluid. Chest CT scan was normal. Bone scan did not suggest any metastatic focus. The patient died a month later still without evidence of local recurrence or pulmonary metastasis.

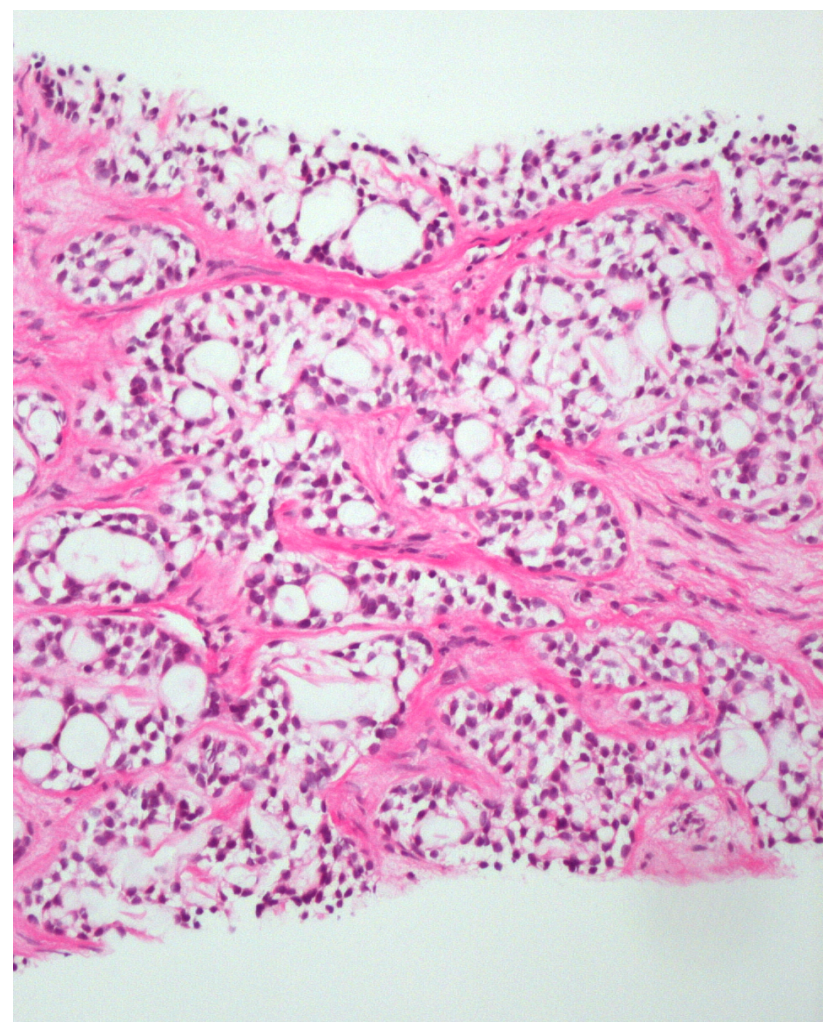

Figure 2: These spaces are not true glandular lumens but represent stromal invaginations (pseudocysts). They are filled with eosinophilic material or basophilic myxoid mucinous material (Magnification, $\times 200$ ).

follow-up, such grade based prognostication is less valid. Currently, stage and tumor location are the only factors considered prognostically significant (5). Radiotherapy has been used as a primary modality for patients with surgical contraindications and in those with unresectable neoplasms. Though no improvement in survival is reported, the use of adjuvant radiation improves locoregional control and disease-free survival. This patient received adjuvant radiation and did not have any locoregional recurrence.

Regional metastasis is less common occurring in about $17 \%$ while systemic failure occurs in 33 to $50 \%$ of the patients (1,2). Through involvement with distant metastases are unpredictable, organs involved in the order of decreasing frequency are lung, bone, brain, and the liver (1). Other rare metastatic sites of the parotid and non-parotid ACC include stomach, toe, choroids, brain, and skin (6). The initial site of metastasis is usually the organ containing the first capillary bed (first filter) and hence lungs would be the common site of metastasis (7). 


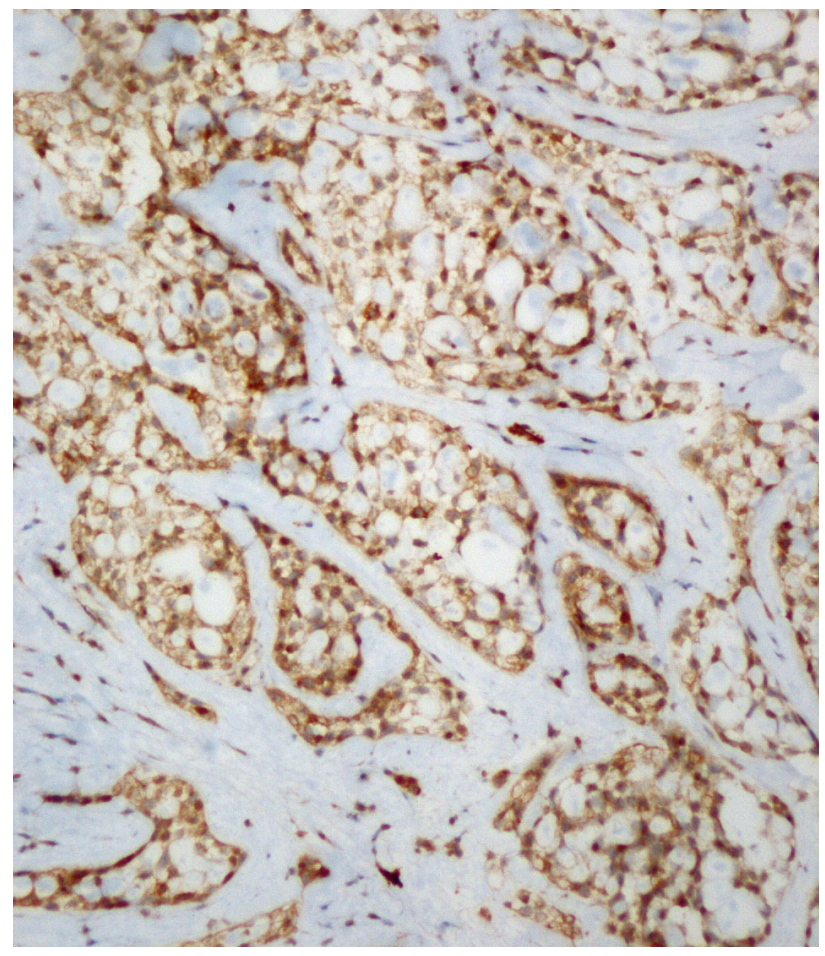

Figure 3: CD117/KIT positive in epithelial cell component ( CD 117, x200).

Clinical observations from various malignancies have indicated that metastasis from certain types of tumor tends to occur in specific target organs leading to the famous 'soil and seed' hypothesis where metastatic cells 'home' to the organ (8). Though liver metastasis has been reported, most of the liver metastases reported are of nonparotid ACC (1). The occurrence is usually metachronous or synchronous with metastasis to other organs like the lung as it is the first filter. In the series of Spiro, of the 74 patients developing metastasis from salivary gland ACC, 23 did so without loco-regional recurrence while 5 had isolated bone metastasis (1). Sung and colleagues found metastases in 46 out of 94 head and neck ACC (9). In that study, only one patient developed liver metastasis and that patient had metastasis to both lung and bone. In this case, the patient manifested with multiple metastatic foci in the liver as the first and only metastatic organ which is very unusual. Surgical options of metastasectomy were not explored as the patient had multiple metastases involving both lobes of the liver. Although the patient lived with the disease for a further two years, she did not show any evidence of lung metastasis or loco-regional recurrence. In this patient, the liver metastasis could have occurred before treatment as an organ of preference; evidenced by the fact that there were no other organs showing metastasis nor was there a loco-regional recurrence later. Studies in ACC have shown long tumor doubling times of pulmonary metastasis and late recurrences up to 10 years after primary treatment. The estimated doubling time of lung metastasis in ACC ranges from 200 to 600 days. There is even a suggestion that metastasis at the cellular level could occur many years before the clinical presentation of the primary tumor. FNAC was done to prove the metastatic foci in this patient and can be a useful tool for diagnosis. Although this patient declined chemotherapy, chemotherapeutic responses have been reported in ACC (10). ACC carries a mortality of $75-80 \%$ over 30 years and most patients who die of their disease do so between 5 and 10 years after initial treatment (5). Our patient died 5 years from diagnosis with metastatic disease that developed 3 years after initial treatment.

ACC is a rare malignant tumor of the parotid gland. Metastasis can manifest very late and hence a long-term follow-up and a high index of suspicion are necessary to diagnose them early. An annual ultrasound study of the abdomen would be desirable on follow-up. Unlike metastasis from other malignancies, these grow indolently and long-term survival can be expected even with multiple metastases as also evidenced in the present case. Chemotherapy could be considered in selected patients as a therapeutic option for metastatic disease.

Conflict of Interest: No conflict of interest was declared by the authors.

\section{REFERENCES}

1. Cockerill CC, Daram S, El-Naggar AK, Hanna EY, Weber RS, Kupferman ME. Primary sarcomas of the salivary glands: case series and literature review. Head Neck. 2013;35(11):1551-1557. DOI: 10.1002/hed.23203.

2. Ishida E, Ogawa T, Rokugo M, Ishikawa T, Wakamori S, Ohkoshi A, et al. Management of adenoid cystic carcinoma of the head and neck: a single-institute study with over 25-year follow-up. Head Face Med. 2020;16(1):14. DOI: 10.1186/s13005-020-00226-2.

3. Seethala RR. Salivary Gland Tumors: Current Concepts and Controversies. Surg Pathol Clin. 2017;10(1):155-176. DOI: 10.1016/j.path.2016.11.004.

4. International Head and Neck Scientific Group. Cervical lymph node metastasis in adenoid cystic carcinoma of the major salivary glands. J Laryngol Otol. 2017;131(2):96-105. DOI: 10.1017/S0022215116009749.

5. Rafael OC, Paul D, Chen S, Kraus D. Adenoid cystic carcinoma of submandibular gland metastatic to great toes: case report and literature review. Clin Case Rep. 2016;4(8):820-823. DOI: 10.1002/ccr3.635.

6. Yurut-Caloglu V, Caloglu M, Ozyilmaz F, Saynak M, Cosar-Alas R, Karagol H, et al. Lung, bone, skeletal muscles and cutaneous metastases from adenoid cystic carcinoma of the parotid gland: a case report and review of the literature. Med Oncol. 2007;24(4):458-462. DOI: 10.1007/s12032-007-0016-x.

7. Dutta A, Arun P, Arun I. Adenoid cystic carcinoma with transformation to high grade carcinomatous and sarcomatoid components: A Rare Case Report with Review of Literature. Head Neck Pathol. 2020;14(4):1094-1104. DOI: 10.1007/s12105-019-01120-3.

8. Umeda M, Nishimatsu N, Masago H, Ishida Y, Yokoo S, Fujioka M, et al. Tumor-doubling time and onset of pulmonary metastasis from adenoid cystic carcinoma of the salivary gland. Oral Surg Oral Med Oral Pathol Oral Radiol Endod. 1999;88:473-478.

9. Sung MW, Kim KH, Kim JW, Min YG, Seong WJ, Roh JL, et al. Clinicopathologic predictors and impact of distant metastasis from adenoid cystic carcinoma of the head and neck. Arch Otolaryngol Head Neck Surg. 2003;129:1193-1197. DOI: 10.1001/archotol.129.11.1193

10. Mehrotra R, Singh M. Diagnosis of hepatic metastasis of adenoid cystic carcinoma of the salivary gland by fine needle aspiration. Cytopathology. 1999;10:216-217. DOI: 10.1046/j.1365-2303.1999.0157a.x. 